Citation: Rodríguez-Falconi, R. Ortiz-García, C. F., Moscoso-Ramírez, P. A., Lagunez-Espinoza, L. del C., \& Osorio-Acosta, F. (2021). Evaluation of chemical resistance inducers in maradol papaya against Phytophthora nicotianae var. parasitica. Agro Productividad. https://doi.org/ 0.32854/agrop. v14il 0.2086

Editor in Chief: Dr. Jorge Cadena Iñiguez

Received: May 12, 2021. Accepted: October 14, 2021. Published on-line: November 12, 2021

This work is licensed under a Creative Commons Attribution-NonCommercial 4.0 International license.

\section{Evaluation of chemical resistance inducers in maradol papaya against Phytophthora nicotianae var. parasitica}

\author{
Rodríguez-Falconi, Rebeca ${ }^{1 *}$; Ortiz-García, Carlos F. ${ }^{1 *}$; Moscoso-Ramírez, Pedro A. ${ }^{1}$; \\ Lagunez-Espinoza, Luz del C. ${ }^{1}$; Osorio-Acosta, Francisco ${ }^{2 *}$ \\ 1 Área de Ciencia Vegetal. Colegio de Postgraduados Campus Tabasco. Periférico Carlos A. Molina, Km 3.5. \\ Carret. Cárdenas-Huimanguillo. H. Cárdenas, Tab. C.P. 86500. \\ 2 Área de Ciencia Vegetal. Colegio de Postgraduados Campus Veracruz. Carr. Xalapa Veracruz km 88.5 Pazo \\ de ovejas, Ver. C.P. 91700. \\ * Correspondence: cfortiz@colpos.mx; rebecarodriguezfalconi1986@hotmail.com
}

\begin{abstract}
Objective: To test the efficiency of four chemical resistance inducers on Maradol papaya to reduce Phytopthora nicotianae var. parasitica infections in rainfed crops at Chontalpa, Tabasco, Mexico.

Design/methodology/approach: Three doses of four resistance inducers were tested on 60-day-old papaya plants in a greenhouse with a randomized design, with four replications and 10 plants as experimental plots. Three days after the inducers' application inoculations with mycelium discs were made, there were negative and positive control treatments to evaluating their efficiency by applying Abbott's formula.

Results: The four chemical inducers for resistance (sodium silicate (SS), potassium silicate (PS), potassium phosphite (PF) and acibenzolar-s-methyl (ASM)) were statistically different from the control $\left(\mathrm{P}<0.0001^{* *}\right)$. The inducers SS 1\%, PS 1\%, FP 0.35\% and ASM 0.1 mM showed higher effectiveness (81.2, 75.9, 74.7 and 74.0 \%). Study limitations/implications: The retained effective concentrations were tested in a single application, and their durability is unknown, so this point should be broadened. however, it may be an alternative for repeated use after transplanting.

Findings/conclusions: Optimal concentrations of SS, PS, FP, and AMS, that respond against P. nicotianae var. parasitica infections can reduce damages in rainfed crops.
\end{abstract}

Keywords: Carica papaya, root rot, Phytopththora n. var. parasitica.

\section{INTRODUCTION}

Papaya root rot (Carica papaya L.) is caused by different Phytophthora species and is worldwide recognized as one of the most important diseases of this crop, as it can occur at any stage of development, from seedling to harvest (Vázquez et al., 2010). This disease was first reported in 1916 in the Philippines, later in 1924 in Ceylon, and then after in other countries such as Malaysia, Hawaii, Australia, Brazil, Spain and Taiwan caused by $P$. palmivora (Ho, 1990). Nevertheless, in India, P. nicotianae. var parasitic was reported as the main causal agent of papaya fruit and root rot (Sukhada et al., 2011). 
In Mexico, in 1976, Garcia-Alvarez reported the presence of root and stem base rot caused by P. parasitica in Colima, Guerrero, and San Luis Potosi. Likewise, in Tabasco, Saldaña et al. (1986), informed the presence of root rot in papaya caused by Phytophthora sp. It was not until 2002 that P. nicotianae var. parasitica was confirmed as the causal agent of the papaya foot rot. Also, Fernández-Pavía et al. (2015) included reports of Phytophthora parasitica as the causal agent of root and stem base rot on a report of plant species diseases in Mexico (Fernández-Pavía et al., 2015). Vázquez et al. (2010) reported the presence of $P$. palmivora at the Huasteca region as the responsible for stem and root rot caused in papaya; although this species is not found in Mexico and is included in the list of pathogens under phytosanitary surveillance (SENASICA, 2016).

In Tabasco, papaya is grown in rainfed conditions, on flatlands with no drainage which is considered as of low technology; using direct sowing or seedlings transplanting, manual weeding control, and a limited application of pest management and disease control (Guzmán et al., 2009). Therefore, during rains, soils are easily saturated and waterlogged, which favors the root rot incidence by up to $11 \%$ (Saldaña, 2002).

Currently, there are control alternatives, such as the induction of systemic resistance, which involves activating plants' natural defense mechanisms through chemical inducers of resistance (Ozeretskovskaya and Vasyukova, 2002), by the pathogens themselves, other organisms, or environmental factors (Park and Paek, 2007). The papaya crop grown in rainfed conditions does not have sustainable management strategies to reduce root damage caused by Phytophthora, and its cultivation process demands using chemical products with low toxicity for mammals and is environmentally friendly. Under this premise, the present research was conducted to assess the effectiveness of chemical inducers for resistance to Phytophthora nicotianae var. parasitica, in transplanted (60 days) Maradol papaya.

\section{MATERIALS AND METHODS}

Isolation. From November to January, four papaya plantations were located in the municipalities of Cunduacán and Huimanguillo. From these municipalities comes the CPA1504 strain of P. nicotianae var. parasitic, isolated from Maradol papaya plants with root rot (Figure 1), proven as its causal agent at the Chontalpa subregion, Tabasco (Rodríguez, 2017).

Production of papaya seedlings in greenhouses. The production of papaya seedlings followed the techniques by Rodríguez and Cruz (2003). Plant emergence was carried out in germination trays with 72 wells, filled with a substrate COSMOPEAT $^{\circledR}$ COSMOCEL) sterilized (autoclave at $15 \mathrm{lb}$ per half hour) two days before used and kept cold; one seed was sown in each well at a one-centimeter depth. The germination trays were protected from the sun, under partial shade, keeping a constant substrate humidity; seedling emergence began after three days.

In vivo test effectiveness of the resistance inducers. The experiment was conducted in a greenhouse, on Maradol papaya seedlings, $60 \mathrm{~d}$ of growth. Four chemical resistance inducers (RI) and three doses of each, were tested: sodium silicate ([Silicatos y Derivados S.A de C.V. A subsidiary of PQ Corporation, density of $1.5 \mathrm{~kg} / \mathrm{L}$ ] were 0.1 , 0.75 and $0.5 \%$ [SS]), potassium silicate ([Silicatos y Derivados S. A de C.V. A subsidiary 

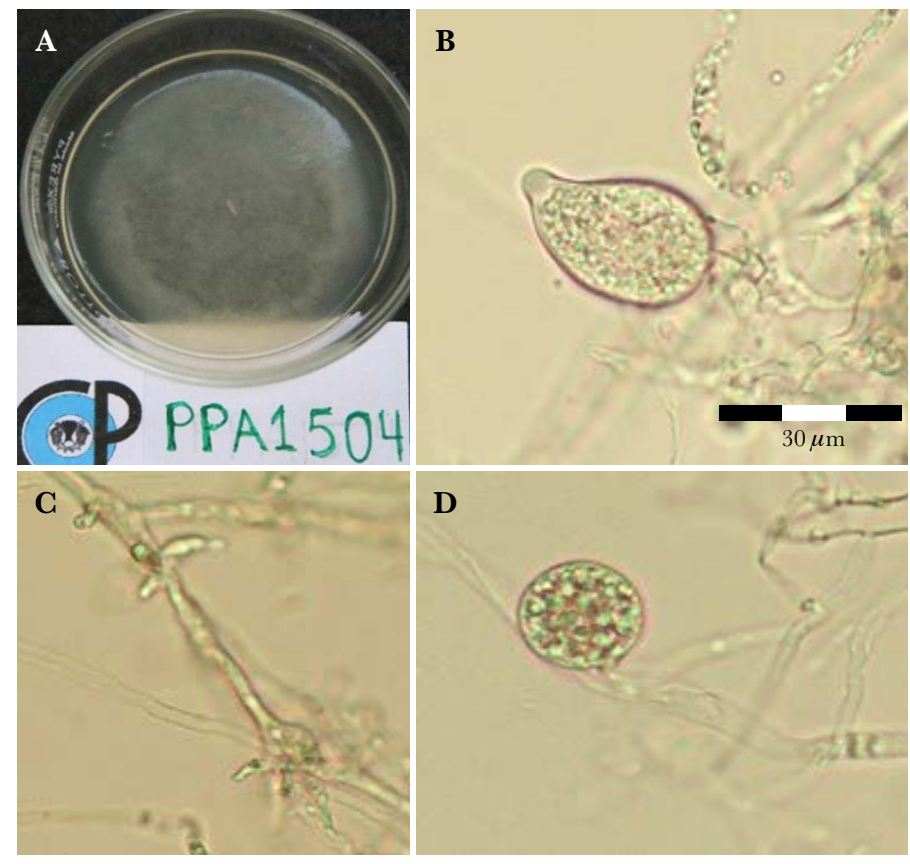

Figure 1. A) General aspect of the CPA1504 colony (P. nicotianae var. parasitica) 4 days after seeding. B) globose sporangium, limoniform with large papilla $\mathrm{C}$ ) branched mycelium, turulose and swollen hyphae. D) terminal chlamydospore.

of PQ Corporation, Sil-MATRIX ${ }^{\circledR}, 29.1 \%$ a.i.] were 1.25, 1 and $0.75 \%$ [SP]), potassium phosphite ([ALIETTE ${ }^{\circledR}$ WDG, Bayer: FOSETIL-Al 80\%. GD]were 0.35, 0.30 and $0.25 \%$ $[\mathrm{FP}])$ and acibenzolar-s-methyl ([Syngenta, Actigard $\left.{ }^{\circledR} 50 \mathrm{GS}\right]$ were $1,0.1$ and $0.01 \mathrm{mM}$ $[\mathrm{AM}]$ ). In addition, a negative control treatment (papaya seedlings sprayed with sterile distilled water, without inoculation [Te]) and a positive control treatment (papaya seedlings artificially inoculated with Phytophthora sp. [Te-]) were included.

The experiment was established with 14 treatments, and four replications, in a randomized complete experimental block design, using sets of 15 papaya plants as the experimental units. The treatments were applied by spraying the plants with a manual atomizer, until they reached dew point, three days before the artificial inoculation. The treated plants, before inoculation, were placed in a humid chamber equipped with a Vitalys $^{\text {plus }}$ ultrasonic humidifier. Mycelial discs from the CPA1504 pathogen strain were used for artificial inoculation (2.5 $\mathrm{mm}$ in diameter) at the base of the papaya seedling stems, placed in a humid chamber, maintaining the humidity for four consecutive days.

Study variables. Daily, for a $10 \mathrm{~d}$ period, the number of dead plants was counted and their survivorship and dead percentages, average days to death per treatment, and the efficacy of the inductor were calculated, using the Abbott formulas (1925) corrected by Rosenhein and Hoy (1987).

$$
\text { Pcorr }=\left(\frac{\text { Psti }- \text { Pste }}{1-P s t e}\right)
$$


Where: Pcorr (corrected survival percentage), Psti (survival percentage of treatment with inducer), Pste (survival percentage of the positive control).

Statistical analysis. Survival percentage data were transformed to Arcosine $\sqrt{Y}$, prior to performing an ANOVA with the SAS V9 statistical software. Statistical significance was considered at a $\mathrm{p}=0.05$ level. Tukey's test was used to separate means. The values shown are untransformed means. Covariance tests between survival and height, survival, and leaf area were also performed in the same statistical software.

\section{RESULTS AND DISGUSSION}

Table 1 shows that the four evaluated resistance inducers were effective and responded, as indicated by Walter et al. (2005), who states that, induced resistance being of broadspectrum, should not always be expected to completely control the infection. Pointing out that the efficacy of chemical inducers on the causal agent of wheat blight disease varied from 20 to $85 \%$. They emphasize that, when the pathogen is highly aggressive, as is the wheat blight case, resistance inducers such as SS and FP did not reduce the disease severity, as they had done in a previous cycle with a less aggressive version of the disease (Pagani $e t$ al., 2014).

Overall, in this research, all treatments with chemical inducers for resistance were significantly effective (37-81\% effectiveness) compared to the negative control, where

Table 1. Chemical resistance inducers effect on root rot in 'Maradol' papaya plants.

\begin{tabular}{l|l|c|c|c}
\hline \multicolumn{2}{c|}{ Treatment* } & \multirow{2}{*}{$\begin{array}{c}\text { Survival } \\
\%\end{array}$} & $\begin{array}{c}\text { Efficacy } \\
\%\end{array}$ & $\begin{array}{c}\text { Days of dead } \\
\text { plants }\end{array}$ \\
\cline { 1 - 2 } \multicolumn{1}{c|}{ Inducers } & Doses & $82.17 \mathrm{ab}$ & 81.26 & 8 \\
\hline $\mathrm{SS}_{1}$ & $1.00 \%^{\mathrm{x}}$ & $45.72 \mathrm{~b}$ & 42.95 & 5 \\
\hline $\mathrm{SS}_{2}$ & $0.75 \%$ & $71.79 \mathrm{ab}$ & 70.35 & 7 \\
\hline $\mathrm{SS}_{3}$ & $0.50 \%$ & $76.22 \mathrm{ab}$ & 75.01 & 8 \\
\hline $\mathrm{SP}_{1}$ & $1.25 \%$ & $77.12 \mathrm{ab}$ & 75.96 & 7 \\
\hline $\mathrm{SP}_{2}$ & $1 \%$ & $71.90 \mathrm{ab}$ & 70.47 & 6 \\
\hline $\mathrm{SP}_{3}$ & $0.75 \%$ & $75.92 \mathrm{ab}$ & 74.70 & 6 \\
\hline $\mathrm{FP}_{1}$ & $0.35 \%$ & $53.38 \mathrm{~b}$ & 51.00 & 7 \\
\hline $\mathrm{FP}_{2}$ & $0.30 \%$ & $64.68 \mathrm{ab}$ & 62.88 & 7 \\
\hline $\mathrm{FP}_{3}$ & $0.25 \%$ & $60.65 \mathrm{ab}$ & 58.64 & 7 \\
\hline $\mathrm{AM}_{1}$ & $1 \mathrm{mM}$ & $75.28 \mathrm{ab}$ & 74.02 & 8 \\
\hline $\mathrm{AM}_{2}$ & $0.1 \mathrm{mM}$ & $40.82 \mathrm{~b}$ & 37.81 & 0 \\
\hline $\mathrm{AM}_{3}$ & $0.01 \mathrm{mM}$ & $95.15 \mathrm{a}$ & 94.90 & 5 \\
\hline $\mathrm{Te}$ & 0 & $0.00 \mathrm{c}$ & 0.00 & 7 \\
\hline $\mathrm{Te}-$ & 0 & & & \\
\hline
\end{tabular}

*Inductors: SS (sodium silicate), PS (potassium silicate), PF (potassium phosphite), AM (acibenzolar-S-methyl), Te (uninoculated control and Te- (negative control). X percentage weight/volume ratio. Groups ( $\mathrm{a}, \mathrm{b}$, ab and $\mathrm{c}$ ), equal letters are not significantly different between treatments (Tukey $\alpha=0.05$ ). The arcsine transformation was applied to the survival percentage values. Untransformed means are shown. 
$100 \%$ of dead plants were quantified in a five-day period. The $1 \%$ sodium silicate treatment was the most effective $(81 \%)$ and delayed the first dead plants eight days (Table 1). Likewise, the $1 \%$ dose of the three tested SS treatments was also the most effective against the root rot, suggesting that SS probably acts as a plant growth regulator which is effective at optimal doses, contrary to conventional fungicides, which increase their effectiveness as the dose increase. This result concurs with those by Li et al. (2012), who used $100 \mathrm{mM} \mathrm{SS}$, on the postharvest to induce resistance in melon (Cucumis melon) to Trichothecium roseum, which reduced the diameter of lesions during storage. Additionally, Moscoso-Ramírez and Palou (2013) reported a SS 90\% efficacy when used at $1000 \mathrm{mM}$ to green and blue rots in 'Valencia' oranges; however, they did not recommend using it, due to the presence of phytotoxicity in the fruit rind during the postharvest at that dose. It is worth pointing out that, in the above studies, higher SS concentrations than those used in this study were used (1\%).

Potassium silicate at a $1 \%$ concentration was the second-best chemical inducer of resistance in this research, with a $76 \%$ effectiveness. In the three tested concentrations, it had a stable effect on the plants, with a survival range of 71 to $77 \%$ (Figure 2) and an efficiency of 70 to $76 \%$; although there were no significant differences among them. Likewise, this chemical inducer showed a mean number of dead plants up until the 7 th day. Reports mention that PS affects Sphaerotheca fuliginea applied on cucumber plants at Culiacán, Sinaloa, with $9.45 \mathrm{~g} \mathrm{~L}^{-1}$ and $18.90 \mathrm{~g} \mathrm{~L}^{-1}$ doses, the latter with a $96.4 \%$ efficacy, although this dose showed phytotoxicity in the crop (Pérez-Angel et al., 2010). Nevertheless, Ramírez et al. (2013) reported that neither SP nor FP had a detrimental effect on P. cinamomi applied on avocado, regarding other organic practices.

Papaya plants treated with FP had a 53 to $76 \%$ survival rate (Figure 2), the $0.35 \%$ dose being the best, with a $75 \%$ effectiveness. The $0.30 \%$ dose showed lower effectiveness, $51 \%$. Whereas the minimum dose treatment showed $0.25 \%$ and $64.6 \%$ effectiveness, with an average death of the first plants within seven days.

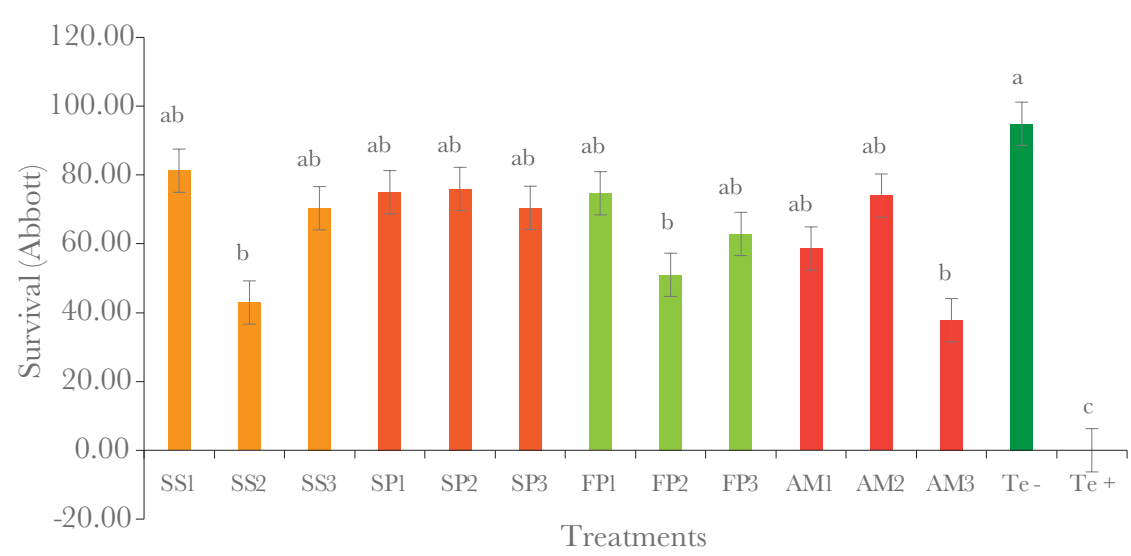

Figure 2. Average survival percentages of 60-day-old Maradol papaya plants, by IR resistance, inoculated with $P$. nicotianae var. parasitica Groups (a, b, ab and c), equal letters are not significantly different between treatments (Tukey $\alpha=0.5$ ). 
These results suggest that PF probably worked as a growth regulator, effective at optimum doses (in this case, PF at 0.35\%). Multiple researchers show the FP efficacy as a control product for important diseases caused by oomycetes, not only on the Phytopthora genus, but also on Peronospora, Plasmopara, and Pythium genera (Groves et al., 2015). Similar results were obtained for wheat blight with $\mathrm{PF}$ when the disease is mild; however, its effect is constrained when the pathogen shows greater aggressiveness (Pagani et al., 2014). In plants of Pinus radiata other wild species, inoculated with P. cinnamomi (soil), at high PF concentrations, showed no significant effect on the pathogen but did cause phytotoxicity on some plants. However, stem injections and PF spraying inhibited P. cinnamomi (Shearer and Crane, 2014).

The third most effective treatment $(74 \%)$ was acibenzolar-s-methyl at $0.1 \mathrm{mM}$. The three applied concentrations had effectiveness from 37 to $74 \%$, with the first plants dying within seven days, being ASM at $0.1 \mathrm{mM}$ the effective dose in the control of papaya root rot. These results also suggest that this resistance inducer acted as a growth regulator. Our results are similar to those reported by Vawdrey and Westerhuis (2007), who showed that $\operatorname{ASM}\left(0.025 \mathrm{~g} \mathrm{~L}^{-1}\right)$ significantly reduced root rot incidence caused by $P$. palmivora on papaya in Australia. Gilardi et al. (2014), on other hand, found that AM at 0.025 and $0.0125 \mathrm{~g}$ i.a. $\mathrm{L}^{-1}$ applied three times before inoculation, produced $100 \%$ efficacy in disease mitigation in the first test. The difference with this research was that it was done with only one application. In the present investigation, the effectiveness (75\%) with ASM $(0.1 \mathrm{mM})$ against the infection of $P$. nicotianae var. parasitica was higher than that reported by Macedo et al. (2009), who observed a survival of 68.3 to $65.3 \%$ in the plants, after three days of inoculation, with a previous application of $0.30 \mathrm{~g} \mathrm{~L}^{-1}$ of ASM in the Golden papaya variety against the pseudofungus $P$. palmivora. Concerning the present research, the highest concentration obtained 16\% more survival, however, in both cases, the survival was higher than $40 \%$ for this resistance inducer. Moscoso-Ramírez and Palou (2013) conducted preventive studies through primary in vivo experiments with resistance inducers to Penicillium spp. in 'Valencia' oranges. They found that ASM at $0.9 \mathrm{mM}(0.2$ $\mathrm{g} \mathrm{L}^{-1}$ ) reduced the green rot incidence by $15 \%$. Furthermore, this resistance inducer also reduced the severity of green rot, but not of the blue rot causal agent. Despite the above, ASM does not always act as an inhibitor of all pathogens. For example, Méndez et al. (2010) evaluated conventional fungicides and resistance inducers among them, where $\mathrm{ASM}$ at a concentration of $0.02 \mathrm{~kg}$ a.i. $\mathrm{ha}^{-1}$, against Pseudoperonospora cubensis infection responsible for downy mildew in melon, and the results showed inefficiency and behavior as the positive control.

\section{GONGLUSIONS}

Mortality of $60 \mathrm{~d}$ of age Maradol papaya plants inoculated with P. nicotianae var. parasitica occurs on average five days post-infection, demonstrating the high susceptibility of the papaya to this pathogen. The four tested chemical resistance inducers: sodium silicate, potassium silicate, potassium phosphite, and acibenzolar-s-methyl, showed significant efficacy in inducing resistance on $60 \mathrm{~d}$ old papaya seedlings inoculated with $P$. nicotianae var. parasitica. 


\section{ACKNOWLEDGMENTS}

The authors thank the Colegio de Postgraduados for funding this research. Rebeca Rodríguez Falconi received a master's scholarship funded by the "Consejo Nacional de Ciencia y Tecnología (CONACyT-588189/304343).

\section{REFERENGES}

Abbott, W. S. (1925). A method of computing the effectiveness of an insecticide. J. Econ. Entomol. 18, (2).265267. https://doi.org/10.1093/jee/18.2.265a

Fernández-Pavía, S. P., Gregorio-Cipriano, R., Rodríguez-Alvarado, G., Mondragon, F. A., Gómez-Dorantes, N., Lozoya-Saldaña, H., Rodríguez-Fernández - Herrera, C. J. (2015). Enfermedades de especies vegetales en México. Primera edición. Universidad Mexicana de San Nicolás de Hidalgo. Morelia, Mich., Mexico. 425p

Garcia- Álvares M. (1976). Primer catálogo de enfermedades de plantas mexicanas. fitofilo 71:45-168.

Gilardi, G., Demarchi, S., Gullino, L., Garibaldi, A. (2014). Managing Phytophthora crown and root rot on tomato by pre-plant treatments with biocontrol agents, resistance inducers, organic and mineral fertilizers under nursery conditions. Phytopathologia Mediterranea. 53,(2).205-215. Doi:10.14601/ Phytopathol_Mediterr-12361

Groves, E., Howard, K., Hardy, G., Burgess, T. (2015). Role of salicylic acid in phosphite-induced protection against Oomycetes; a Phytophthora cinnamomi-Lupinus augustifolius model system. Eur. J. Pathol. 141:559569

Guzmán, E., J., Gómez R., Pohlan J., Álvarez J. (2009). Evaluación financiera de la producción de Papaya en Tabasco, México, por tecnologías Baja, Media y Alta. Revista de la Ingeniería Industrial. 3, (1).1-23.

Ho H. H. (1990). Taiwan Phytophthora. Bot Bull Acad Sinica. 31:89-106.

Li W., Bi Y., Ge Y., Li Y., Wang J., Wang Y. (2012). Effects of postharvest sodium silicate treatment on pink rot disease and oxidative stress-antioxidative system in muskmelon fruit. Eur. Food Res. Technol. 234.137145

Macedo, T. G., Laranjeira, D., Newman, L. E. D. M., Ribeiro, S. T., Priminho, R. C., Vilela de, R. M. L., RibeiroJ. P. M. (2009). Inducao de resistencia do mamoeiro a podridao radicular por indutores bióticos e abióticos. Pesq. Agropec. Bras., Brasilia. 44, (11).1416-1423. Doi: 10.1590/S0100-204X2009001 100007

Méndez, L. W., Arauz, L. F., Ríos, R. 2010. Evaluación de fungicidas convencionales e inductores de resistencia para el combate de Mildiú Velloso (Pseudoperonospora cubensis) en melón (Cucumis melo). Agronomía Costarricense. 34, (2).153-164.

Moscoso-Ramírez, P. A., Palou L. (2013). Evaluation of postharvest treatments with chemical resistance inducers to control green and blue molds on orange fruit. Postharvest Biology and Technology. 85.132135. Doi: 10.1016/j.postharvbio.2013.05.013

Ozeretskovskaya , O. L., Vasyukova N. I., Zinoveva S. V. (2002). The Use of Elicitors for Protection of Cultured Plants Demands Caution. Applied Biochemistry and Microbiology. 38, (3). 277-279. Doi: 10.1023/A:1015483727383

Pagani A. P. S., Dianese A. C., Café-Filho A. C. (2014). Management of wheat blast with synthetic fungicides, partial resistance, and silicate and phosphite minerals. Phytoparasitica. 42, 609-617. Doi: 10.1007/ s12600-014-0401-x

Park J. M., Paek K. H. (2007). Recognition and response in plant-pathogen interactions. Journal of Plant Biology. 50(2), 132-138. Doi: 10.1007/BF03030621

Pérez-Ángel, R., García-Estrada, R. S., Carrillo-Fasio J. A., Angulo-Escalante, M. A., Valdez-Torres J. B., Muy-Rangel M. D., García López A. M. (2010). Control de cenicilla (Sphaeroteca fuliginea Schlechtend.: Fr, Pollaci) con aceites vegetales y sales minerales en pepino de invernadero en Sinaloa, México. Rev. Mexicana de Fitopatología. 28, (1).17-24.

Ramírez, G. J. G., Castañeda S. D. A., Morales O. J. G. (2013). Dinámica microbial del suelo asociada a diferentes estrategias de manejo de Phytophthora cinnamomi Rands en aguacate. Revista Ceres, 60 (6): 811-819. Doi: 10.1590/S0034-737X2013000600009.

Rodríguez, N. A., Cruz F. J. (2003). El cultivo de la papaya 'Maradol' en la Mixteca Baja. Agrotecnia. FUPPUE-SDR-DGT-SAGARPA. ITA No. 32. FIRAINIFAT. Puebla, Puebla. México. 24 pp.

Rodríguez, F. R. (2017). Evaluación de inductores químicos de resisitencia contra Phytophthora sp en papaya Maradol. Colegio de Postgraduados. Tesis de Grado Maestría en Ciencias. Tabasco. 76p.

Rosenhein, J. A., Hoy, M. (1987). Confidence intervals for Abbott's Formula correction of bioassay data for control response. J. Econ. Entomol. 82(2). 331-335. Doi: 10.1093/jee/82.2.331 
Saldaña, M. H., Marquez, M. M., Ruiz, B. P. (1985). Identificacion de las enfermedades fungosas del cultivo de papaya (Carica papaya L.) en el estado de Tabasco. Revista Mexicana de Fitopatologia 3. 14-17.

Saldaña, H. M. I. (2002). Diagnóstico de la pudrición de la raíz del papayo causado por Phytophthora sp., en la Chontalpa y Centro Tabasco. Colegio de Postgraduados. Tesis de Grado Maestría en ciencias. Tabasco. 110p.

Shearer, B. L., Crane, C. E. (2014). Phytophthora cinnamomi disease expression and habitat suitability of soils on a topographic gradient across a coastal plain from dunes to forested peneplain. Australasian Plant Pathology, 43 (2).131-142. Doi: 10.1007/s13313-013-0255-6

Sukhada, M., Manjula, R., Rawal, R. D. (2011). Evaluation of arbuscular micorrhiza and other biocontrol agents against Phytophthora parasitica var. nicotianae infecting papaya (Carica papaya cv. Surya) and enumeration of pathogen population using inmuno techniques. Biological Control. 58. 22-29.

Vázquez, G. E., Mata, V. H., Arriza, F. R., Santamaría, B. F. (2010). Producción y manejo postcosecha de papaya Maradol en la planicie Huasteca. Libro Técnico N4. INIFAP. 156 p. http://www.inifapcirne. gob.mx/Biblioteca/Publicaciones/855.pdf

Vawdrey, L. L., Westerhuis, D. (2007). Field and glasshouse of metalaxyl, potassium phosphate, acibenzolar and tea tree oil in managing Phytophthora root rot of papaya in far northern Queensland, Australia. Australasian Plant Pathol. 36,(3). 270-276. 